\title{
WORLDVIEW OF BELARUSIAN FOLK SONG LYRICS
}

\author{
Yanina Hrynevich \\ Center for Belarusian Culture, Language and Literature Research \\ National Academy of Sciences, Belarus \\ e-mail: yaninahrynevich@gmail.com
}

\begin{abstract}
This article concentrates on Belarusian folk song lyrics. Song lyrics were first recorded in the 1840s. Today, Belarusian folk song lyrics are a sufficiently widespread genre in the countryside. Although new plots are not created, plots known from the first recorded lyrics are prevalent everywhere. However, previously the worldview of Belarusian folk song lyrics was not the subject of research. Therefore, the aim of the article is to show the unique and specific worldview of these songs.
\end{abstract}

Keywords: Belarusian folklore, Belarusian folk songs lyrics, worldview

\section{INTRODUCTION}

Belarusian folk song lyrics are a large part of Belarusian folklore. In contrast to the ritual songs which are functionally related to agriculturists' work throughout the year, and the basic stages of human life (birth, marriage, and death), folk song lyrics reflect the social aspects of human existence. They include love, family, social, and humorous songs. Their characteristic features are:

- Absence of connecting to a certain rite stage. The main task of the lyrical songs is to express feelings, attitudes to certain phenomena of reality in contrast to the sacral-magical and utilitarian functionality with regard to ceremonial poetry. In folk song lyrics "the expression of feelings and personal experiences isn't limited" (Mažejka 2008: 122);

- Variability in Belarusian folk song lyrics;

- The special musical character of folk song lyrics in comparison to ceremonial lyrics, as well as other lyrical genres;

- The predominance of the ideological and emotional component over the narrative: the human being is interpreted in the light of experiences and feelings, and the main attention is focused on the discovery of the inner world, 
the transmission of psychological states, thoughts, etc. In the center of the song, as Hurski has shown, "it is always a person (lyrical hero or heroine), personal destiny, thoughts, feelings and experiences arising from both subjective features of the relationship with relatives... and the circumstances of the social environment, public life" (Hurski 2002: 3);

- Commonality of poetic principles and methods of the songs' textual organization.

Lyrics describe the most important stages of human life: the adolescent years or a period of family life as well as the lives of individual population groups. Lyrical heroes are divided according to their social status, sexual age (woman, man), family (husband, wife, mother, father, mother-in-law, etc.) and professional status (Cossack, soldier, Chumak, Burlak, etc.). These songs do not create a complex psychological image and represent only the most general, stereotypical mental states in particular (and typical) situations.

Today Belarusian folk song lyrics persist as one of the most widespread genres of Belarusian folklore. They are well represented in printed editions of folklore of the nineteenth-twenty-first centuries. Collecting and publishing the songs started in the 1840s. There are the following stages: 1 ) from the 1840 s to the $1920 \mathrm{~s} ; 2$ ) from the 1920 s to the $1970 \mathrm{~s} ; 3$ ) from the 1970 s to the beginning of the twenty-first century.

The period between the 1840s and 1920s is characterized by initial collecting, processing, and publication of works of different folklore genres. The largest collection of folk song lyrics is contained in the collections of Czeczot (1844, 1846), Tyszkiewicz (1871), Gil'tebrant (1866), Shein (1873, 1874), Radchenko (1888), Romanov (1886), Dobrovol'skiy (1903), Bulgakovskiy (1890), Harecki and Jahoraŭ (1928), and others. Also Belarusian folk songs came to the attention of foreign - Polish (Federowski 1958, 1960, 1969; Kolberg 1968) and Czech (Kuba 1887) - researchers in this period.

From the 1920 s to the 1970 s, the situation changed significantly. The research focus moved mainly to "contemporary folklore", which reflected the October Revolution, class struggle, collectivization, and other processes, but in the collections of Šyrma (1959, 1960), Sacharaŭ (1940), Hilievič (1976), Čurkin (1949), and Citovič $(1959,1975)$ considerable attention was paid to Belarusian folk song lyrics.

The next period is characterized by the publication of the thematic series (multivolume edition Belarusian Folk Art, the volumes of which, titled Love Songs (Fiadosik 1978), Family Songs (Fiadosik 1984), and Social Songs (Fiadosik 1987) are dedicated to folk song lyrics), and regional collections of Belarusian folklore (the multi-volume edition Traditional Artistic Culture of the 
Belarusian People in six volumes (Varfalamiejeva 2001-2013), and others, which show the richness and local specificity of folklore.

Theoretical studies of Belarusian folk songs were started by Karskiy (2007 [1916]: 243-259). He identified the main themes; revealed the semantics of some images; discovered the specifics of rhythmic and melodic patterns, rhymes and stanzas; and revealed correlations with songs of other Slavic nations. Some conclusions are subjective but, nevertheless, his study is the first attempt to systematically study the main Belarusian folklore genres.

Further study of poetry continued in the 1960s mainly in literary folkloristics. The problems that were considered related to classification; genesis; ideological and thematic content; poetics; comparative analysis of the folk songs of Slavonic peoples; rhythmic and melodic structure; moral, ethical and aesthetic aspects; folklore and literary interaction, and historiography (Hilievič 1968, 1975; Hliebka 1975; Hrynblat 1967, etc.).

At the beginning of the twenty-first century, focus was given to textual complexes not of genre relations, but as a complicated system of codes. The dendrological and coloristic codes were systematically described by Švied (2006, 2011a). Also landscape-topographical, astronomical, animalistic, and somatic codes were described to a certain extent. When studying these codes in varying degrees, Belarusian folk song lyrics were used.

Like every folk genre, Belarusian folk song lyrics create a unique and specific worldview, ${ }^{1}$ the study of which opens up prospects for the description of the general folk worldview.

\section{METHODS OF RESEARCH AND SOURCES}

Study of worldview is carried out through a thesaurus description of its units (keywords), based on the model of thesaurus description of folk poetry language, which was offered by Serafima Nikitina. Keywords are determined by the frequency of use, word-forming capabilities, involvement of the words in idioms/formulas, and additional cultural or semantic loading. With the help of the model, fixed semantic connections of keywords in the text are made, which further allows the location of each individual image in the worldview to be determined (1993).

Keywords are characterized by the following functions (semantic relations): synonyms; isofunctional words; antonyms; hyponyms - hypernyms; plurality - the main element of plurality; part - whole; object - internal attribute; object - external attribute; measure, number, amount; object/action - locus; 
subject - action; addressee - the action; object - the action; instrument - the action; implication; metamorphosis; associative complex, and individual functions. Nikitina says that they "provide an opportunity to see how deep and diverse are connections of the title unit with other words and expressions of folklore language on the number of completed items/functions and the number of words and phrases in these points" (Nikitina 2006: 75).

Quantitative analysis revealed the most frequent images of Belarusian folk song lyrics. It was carried out on the basis of the book The Lyric Songs by Hilievič (1976), which includes love, family, social, and humorous songs (I have not taken into account songs for dances and ditties). The selection is based on the high scientific level of publication and a sufficient number of well-preserved songs, recorded within the same time period.

The empirical basis for the description of the keywords was also constituted by the following collections: Love Songs (Fiadosik 1978), Family Songs (Fiadosik 1984), Social Songs (Fiadosik 1987), Belarusian Folk Songs (Šyrma 1959, 1960), and others.

The reasons for preferring printed sources to analyze folk songs is that the most complete of them are based on the materials of the largest and oldest folklore archive of Belarus - the Collection of Folklore Recordings, which is stored at the Center for Belarusian Culture, Language and Literature Research of the National Academy of Sciences of Belarus. The collection includes materials of field expeditions of the institute (since 2012 it has been called the Center for Belarusian Culture, Language and Literature Research) staff (1960-2016); manuscripts which were submitted to the Best Folklore Collector contest; materials from archives of Belarusian universities, and from private archives donated by writers, cultural figures, researchers, etc. So printed editions contain the most complete collections of all types of Belarusian folk song lyrics based on the diversity of themes and variations.

\section{WORLDVIEW: STRUCTURE AND SEMANTICS OF ELEMENTS}

In Belarusian folk song lyrics, the world consists of heaven and earth, referring to a vertical orientation, but at the same time the east-west axis is important (the Belarusian folk model focuses on the motion of the sun).

The heaven in the songs is the "mirror" of what is happening on the ground. We can learn/hear from the song about the most important, significant events. In a small group of songs heaven appears as God's location. Also, astronomical objects are located there: the sun, the moon, stars. 
The semantics of the astronomical images are associated with the sphere of family relations - they embody the characteristics of songs: sun - a mother, a young woman, a father, the old man; moon - a father; star - a daughter, a mother, a sister. The time of day is encoded in astronomical images. Sunset (expressions such as the sun set, the sun is low), the rising of the moon and stars, and the appearance of stars in the sky indicate the occurrence of the dark time of the day - evening, night. Sunrise or dawn indicates the onset of the morning. Sunlight is associated with daytime.

In the Belarusian folk songs, the sun is the most semiotically loaded image among the astronomical objects. Its location is characterized by remoteness (behind a pinery, on the hill, over the hill, behind an oak forest). The main activities related to the image of the sun can be divided into several groups: movement (to roll, to go, to rise), the impact on the result (to heat, to dry, to burn $u p$ ), the location in reference to the object (to sit in front of, to stand in front of) and other activities (to stitch, to look at). The main epithet hot accentuates natural characteristics; the attributes bright or clear emphasize belonging to the sphere of the Sacred.

The ideal situation is often modeled by using an image of the sun, and the lexeme opens an associative sequence, beginning with the description: Sonca hreić, viecier vieić, žyta palavieić... (The sun is heating, the wind is blowing, the rye is maturing...) (Hilievič 1976: 127). Violation of the order points out a problem, an "irregular" situation. The solution of the problem constitutes the storyline situation of the song. In the state of disease, age-old order is perceived as negative, bringing suffering.

Astronomical objects (moon, stars) in Belarusian folk song lyrics are in the active position: they are the subjects of the action. The main activities related to the images of the moon and stars can be divided into two groups - directional movement and lighting.

In the songs the earth is the epitome of femininity (expressions such as earthmother): "Moj milieńki zvalicca, Ab ziamliu udarycca: Ni mnie, ni tavaryšcy Syroj ziamli-matušcy" (My dear young man fell down, hitting the ground, do not get me or a friend, but the damp earth-mother...) (Hilievič 1976: 136). The associative complex damp land-yellow sand reflects the semantics of the burial place, the grave: "Žoŭcieńki piasok, syraja ziamlia, Tut pachavana milaja maja” (Yellow sand, damp earth - here my dear is buried) (Hilievič 1976: 106).

Heaven and earth form the world - a space which is inhabited by people. The adverbs all and whole point out the finiteness of the world. This also indirectly indicates the following situation: “-Zakružylasia haloŭka, Sercajka balici. Oj, nie znaju, nie viedaju, Jak mnie pieražyci. - Čym ciabie liačyć, dačuška, I dzie 
ciabie dzieci? - Oj, nie nojdzieš mnie liakarstva, Mamačka, na sviecie” (- Head spun, Heart hurts. Oh, I do not know, I do not know how I can survive. - How should I treat you, daughter? Where should I put you? - Oh, you do not find a cure, Mommy, in the world) (Hilievič 1976: 116). Most often the lexeme world is an object (to pass, to not let go, to find, to give birth, to light, etc.) but may also be the subject of an action (to come, to (already) change, to go, etc.). This change in the age-old world order has a clear negative connotation: "Jaki ž ciapier sviet nastaŭ, To šče nie byvala: HIabje žonka mužyčeńku..." (What in the world is going on now? This has never happened before: the wife has hit her husband...) (Hilievič 1976: 320).

Motifs of birth and meeting the destiny as a result of an unhappy marriage, departure to military service, and parting connect with the lexeme. They are also used in contexts when it comes to wanting to die: "Ja ciabie, niaviestka, nie vady slala, Ja ciabie, niaviestka, z svietu zbaŭliala" (I haven't sent you, daughter-inlaw, for the water, but I wished you, daughter-in-law, to die) (Hilievič 1976: 203).

In Belarusian folk song lyrics, the following calendar-chronological images are represented: time of day (morning, afternoon, evening, night), day of the week (Monday, Tuesday, Wednesday, Thursday, Friday, Saturday, Sunday), seasons (winter, spring, summer) and lexemes (today, yesterday, tomorrow).

In Belarusian folk song lyrics morning begins the day and is a period of activity, working on the farm:

U paniadzielak ranicoj Kasiŭ baćka siena.

Kasiŭ baćka, kasiŭ ja-Kasili my dvoje.

U aŭtorak ranicoj Sušyŭ baćka siena.

Sušyŭ baćka, sušyŭ ja-Sušyli my dvoje.

U sieradu ranicoj Zhrabaŭ baćka siena.

Zhrabaŭ baćka, zhrabaŭ ja - Zhrabali my dvoje.

Ranicoju u čacvier Vaziŭ baćka siena.

Vaziŭ baćka, vaziŭ ja - Vazili my dvoje.

U piatnicu ranicoj Pradaŭ baćka siena.

Pradaŭ baćka, pradaŭ ja - Pradali my dvoje.

U subotu ranicoj Prapiŭ baćka hrošy.

Prapiŭ baćka, prapiŭ ja - Prapili my dvoje.

U niadzieliu uvieś dzień Plakaŭ moj baćka.

Plakaŭ baćka, plakaŭ ja - Plakali my dvoje.

(Hilievič 1976: 298)

Monday morning Father mowed hay.

I mowed, my father mowed - mowed the two of us.

Tuesday morning Father dried hay. 
I dried, Father dried - dried the two of us.

Wednesday morning Father raked hay.

Father raked, I raked - raked the two of us.

Thursday morning Father transported hay.

Father transported, I transported - the two of us transported.

Friday morning Father sold the hay.

Father sold, I sold - sold the two of us.

Saturday morning Father drank the money away.

Father drank away, I drank away - the two of us drank away.

Sunday all day my father cried.

Father cried, I cried - cried the two of us.

The emergence of dew, the sunrise, the dawn, and the crowing of the rooster point to the onset of the morning. The nightingale is an animalistic equivalent of the morning. That is why it is characterized by the epithet early: "Salaviej, salaviej, Ptaška ranniaja, A papiej, salaviej, Piesni raznyja" (Nightingale, nightingale, early birdie, sing, nightingale, different songs) (Hilievič 1976: 270).

In Belarusian folk song lyrics Sunday morning received the greatest semiotic load: that time is central to the development of the plot - the lyrical hero dies: "Pamior, pamior pa Ǔkrainie Kazak maladzieńki. Oj, jon pamior, oj, jon pamior, U niadzieliu rankam, Oj, prybrali, nalažyli Ǔ sviaciolcy na laŭku" (The young Cossack died, died in Ukraine. Oh, he's dead, oh, he died on Sunday morning, oh, remove him, put him on the bench in the upper room) (Hilievič 1976: 78).

The lexeme day is used in two senses: "daytime / the period between sunrise and sunset" or "the day as a whole". In the first meaning the lexeme is characterized by the epithet white. Day is a period of time for agricultural and household work. In Belarusian folk song lyrics, day is the subject (to start, etc.) and object (to sleep, etc.) of actions.

In the meaning "day as a whole" the lexeme is combined with numbers one, two, three:

Siarod horada slučylasia biada:

Zabaliela ǔ čumačeńki halava.

Liažyć čumak dzień, liažyć i druhi-

Nichto jaho nie spytaje, čym ža jon balion.

Naviedaŭ jaho tavaryš jaho.

(Hilievič 1976: 43-44)

In the city disaster happened:

The Chumak has a headache.

The Chumak lies one day, and the second -

No one asks whether he was ill. 
It shows that the lexeme is often a unit of measurement (to walk, to do, to cry, to lie, to drink, etc. a day).

The lexeme day is opposed to night - the period from sunset to sunrise, the dark time of the day, accompanied by the appropriate attributes - late, dark, invisible. During this time agricultural and household work should be completed: people reap or work until nightfall. In the song lyrics night stands for a period of time that needs to be waited for. Night, as Valodzina says (2011: 330 ), is a dangerous time, "associated with the activity of the representatives of the other world of all ranks and grades". For example:

Bylo ŭ matki dzieviać synoŭ, Mother had nine sons,

Dačka malada-dziesiataja. a young daughter - the tenth.

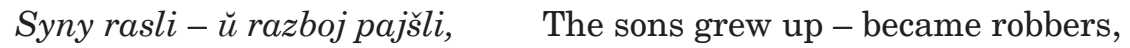

Dačka rasla - zamuž pajšla the daughter grew up -

Za kupčyka-malajca. got married to a merchant.

Jon pajechaŭ kupcavać, He went to trade, A jaje kinuŭ šynkavać. left her to sell vodka. Jechaŭ polie i druhoje, Na treciaje uzjazdžaje Jaho nočka sustrakaje. He went to the first field and the second, enters the third night falls.

Pryviazaŭ kania k biarozie, He tied his horse to a birch,

Sam lioh spać na vozie. he went to sleep on the cart.

Adkul bralisia razbojniki: Jany jaho dy j zabili, Pad kalodu padkacili, Jaho zolata zabrali, Sami sieli j pajechali. (Hilievič 1976: 288) The robbers appeared from nowhere: they killed him and put him under the wood block, took away his gold, sat down and drove away.

The lexeme night is also often combined with the epithets summer and small. In this context, the emphasis is on its short duration: "Lietnia nočka malieńka Ja nie vyspalasia. A ja dnia ǔkaraču, Lietniu ijučku nadtaču" (The summer has a small night - I haven't slept. I will shorten the day, I will lengthen the summer night) (Hilievič 1976: 158).

The sunset designates nightfall:

Jarka sonca zakacilasia, The bright sun had set, Matka ǔ dački zahascilasia. the daughter stayed at Mommy's home for a long time. 
'Oj, praviadu svaju mamačku Za try liasy, za try ciomnyja. Za try liasy, za try ciomnyja, Za try haiki zialionyja.'

Nazad matka ahlianulasia:

Niešta dačka spatyknulasia.

'Ci travička nožki sputala,

Ci rasička vočki vyjela?’

'A sputala dy mnie nožački

Usio čužaja dy staronačka.

A vyjela dy mnie vočački

Usio lichaja dy sviakruchnačka.'
'Oh, I would have seen off my mommy for three forests, three dark forests, three green forests, three dark forests, three green groves.'

After that Mom looked back the daughter stumbled. 'Had grass confused my legs or dew eaten out my eyes?' 'Alien land ate my feet. My wicked mother-in-law

(Hilievič 1976: 249)

In general, leaving the road in the middle of the night (expressions such as to go against), a period which does not provide for activity, does not predict anything good but leads to undesirable consequences: "Nie jedź, braciejka, Nia jedź, rodnieńki, Proci ciomnaje nočy: Ty sam nie chrabry, Tvoj koń nie ŭbrany, Budzieš ty asmiajany" (Don't go, my brother, don't go, my dear, against the dark night: you aren't brave, your horse isn't harnessed, you will be ridiculed) (Hilievič 1976: 145). In the texts the lexeme night is also a unit to measure time (to walk, to [not] sleep, to talk, to sit a night). The associative complex day - night represents "constant" and "permanent": "Oj, u poli jeĺ zialionaja, U niaviestki sviakroŭ šalionaja. Žuryla maladu jak dzień, tak noč, Prahaniala ad siabie proč" (Oh, green fir stands in the field, daughter-in-law has made mother-in-law angry. She scolds the young girl all day and night and banishes her) (Hilievič 1976: 286).

Widespread elements of songs are all the days of the week:

U paniadzielak spliu, spliu,

U aŭtorak snapoŭ sorak

Pšaničački žnu, žnu.

U sieradu vazila,

U čacvier malacila,

U piatnicu viejala,

U subotu mierala, A ŭ niadzieliu pradala

I $z$ chlopcami prapila.

(Hilievič 1976: 318)
On Monday, I slept, I slept.

On Tuesday forty sheaves of wheat I reaped, I reaped.

On Wednesday I drove.

On Thursday I threshed.

On Friday I winnowed.

On Saturday - took measurements, and on Sunday I sold and drank away money with the guys. 
This example points out that the days from Monday to Saturday suggested active work (agricultural and household), and Sunday was intended for rest. The lexeme Monday forms an associative complex with Tuesday. The lexeme Sunday is the most frequent and most semiotically loaded calendar-chronological image. It is used in two senses: "day of the week" and "week in general". As a day of the week, it is characterized by the epithet holy. Symbolic, momentous events happen on this day: the birth of a child, marriage, departure to military service, burial, the drowning of a child, and meeting with God. The lexeme Sunday often forms an associative complex with Saturday.

In Belarusian folk song lyrics, key events take place from Saturday to Sunday. For example, the stepmother becomes ill and sends the orphan to the forest to pick berries:

Z subotki na niadzieĺku Mačycha zachvarela, Mačycha zachvarela, Jahadak zachaciela.

Vypravila sirotku U syr-bor pa jahodku.

Užo na dvare abide - Sirotački z jahad niet.

Na dvare viečareić - U tatački duša mlieić.

'Kab jana ŭtapilasia - Usie ravy papaŭnieli b,

Kab jaje vaŭki zjeli - Usio polie skryvavili b.'

(Hilievič 1976: 29)

From Saturday to Sunday Stepmother was ill,

Stepmother was ill and wanted some berries.

She sent the orphan to the damp pinery to pick berries.

There isn't an orphan in the yard at lunchtime.

The courtyard got dark - Daddy's soul thrilled.

If she drowned herself - all the ditches would have filled with water,

if wolves ate her - fields would be full of blood.

The road to the forest to pick berries correlates with a distant and dangerous road to the alien world and does not provide a happy solution.

The lexeme week represents the semantics of a "sufficient" period of time for meeting with relatives - parents/wife. Its duration and adequacy is stressed by the use of the epithet whole.

The lexemes yesterday, today, and tomorrow are often used as part of associative complexes. On the one hand, such complexes represent duration, frequency, a long period. For example, the lyrical heroine concludes that "the young man has forgotten her" if he did not visit her yesterday or today. On the other hand, such lexemes are in opposition: "Oj, ja ǔčora byla pjana, A siahonnia pachmialilasia. Učora z mužam byla dobra, A siahonnia pasvarylasia” (Oh, I was drunk 
yesterday, and now I have a hangover. Yesterday my husband and I were well, and now we quarreled) (Hilievič 1976: 263) or:

- Siahonnia ja z vami,

A zaŭtra pajedu.

Budziěs, mila, pryliahaci

Až da majho sliedu.

- Ni ja pryliahala,

Pryliahać nie budu.

Žyla, milieńki, z taboju,

I biez ciabie budu.

(Hilievič 1976: 109)
- Today I am with you, and tomorrow I will go.

You, my dear, will lie down on my footprint.

- I didn't lie down,

I wouldn't lie down.

I lived, my dear, with you,

and I will live without you.

Often, use of such associative complexes (yesterday - today, today - tomorrow) points to departure, a parting.

Separately, not as a part of an associative complex, these lexemes are used for a specific interval of time that is important for the development of the story. The lexeme tomorrow is used for the nearest future. Tomorrow (Sunday) is a momentous event for the heroine - the wedding.

Space is presented in the natural (field, river, forest, meadow, sea, valley, beach, mountain, wellspring, the Danube, grove, oak groves, etc.) and cultural (garden, road, window, house, yard, inn, gate, grave, storage room, porch, door, bridge, Ukraine, Crimea, etc.) objects. In Belarusian folk song lyrics, they perform a number of typological features - they mark the place of action, semantically reflect a center where emblematic events happen and are related to our own or the alien world; they indicate the boundary locus.

The image of garden semantically reflects "our" space; images of Ukraine and Crimea are "alien". Characteristics of the frontier are shown in grove, road, tree, forest, sea, bridge, the river, the Danube, etc.; the same semantics are found in associative complexes of the type three forests, three dark forests, three green pineries, three wide fields, three deep seas, three forests, dark forests, three green gardens, etc.

The image of field is the most semiotically loaded natural object. Synonyms of the lexeme field as space-treated, cultivated territory are cornfield and garden; and its antonyms are forest and mountain (opposed to the field in a vertically situated hierarchy). The specific epithets wide, flat, gold, moneyed, clear, deserted, stony, sandy, and barren indicate the ambivalence of the image. Actions related to agricultural activities and land processing (to plow, to reap, to sow, to harrow, to weed, to grind, etc.) characterize the field as an assimilated, ennobled space. This image is associated with lovers' meeting (the verbs to walk, to fall in love, to hug), a soldier's death, meeting with personalized death, loss 
of virginity, or searching for a happy destiny. In Belarusian folk song lyrics field is also a measure of distance.

In the songs forest, grove, and pinery, which are contextually synonymous in meaning with "the natural locus", are outside the cultural space and relate to such motifs as checking the moral qualities of the girl and loss of virginity:

Dziaǔčynačka pa baru chadzila, The girl went to the forest, maladaja ŭ baru zabludzila. she got lost in the forest.

Prybludzila k zialionamu dubu; She came to the green oak.

- Vot ja tut ža načavać budu. - So I would spend the night there.

Ja dumala, što dub zielianieńki, I thought that it was a green oak ažno ž heta kazak maladzieńki. but it was a young Cossack.

- Vot vaźmu ja harelki paŭkvarty, - - I would take half of a bottle of vodka zaprabuju $\breve{u}$ dziaǔčynački praŭdy. and ask the girl to tell the truth.

- Vaźmi sabie kvarcinu, druhuju, - Take a bottle, and a second, nie abmanieš mianie, maladuju. $\quad$ you will not deceive me, young one.

Jak uziaŭ dziaǔčynu za bieluju ručku, He took her white hand zavioŭ dziaŭčynu pad bielu biarozu, and deceived a girl under the white birch, zavioŭ dziaŭčynu pad bielu biarozu, deceived a girl under the white birch, tam abmanuŭ nie pjanu, cviarozu. deceived a sober girl.

(Fiadosik 1978: № 362b)

In the context, the motif of drinking alcohol (vodka) is actualized, and it is connected with the loss of virginity, an unhappy fate, and meetings and marriage.

News about conscription comes out of the forest:

Oj, z-pad liesu, liesu ciomnaha, z-pad javara z-pad zialionaha vyliatala chiža ptašačka, vynasila hasudarski prykaz.

Čutno-vidno, buduć nabor nabirać, katoraha nam synočka addać...

(Fiadosik 1987: № 12)

$\mathrm{Oh}$, out of the forest, dark forest, from the green sycamore a bird of prey flew, brought the king's orders.

I have heard, I have seen they would send someone to recruit, which son should we give to recruit...

It is distinctive that this news is brought by birds (bird of paradise, gray bird, etc.), which are mediators between "our own" and the "alien" world.

In Belarusian folk song lyrics, the valley is a low-lying area and the opposite of the mountain. In the valley grass, viburnum, people, a girl, a Cossack 
(deceased), two injured young men, a horse, a grave, and personalized death are located. Typical actions that take place in the valley - to bury, to freeze, to go astray, to lie (the body), to sit (personalized death), to go, to meet, to walk, to run - emphasize the link of the locus with the "alien" world: "Tvajho muža, tvajho muža na halovačkach niasuć, scharanili, scharanili pry šyrokaj dalinie" (They carry your husband, your husband on the heads, bury, bury him in the wide valley) (Fiadosik 1987: № 282). As we can see from the last example, the image of valley in songs is semantically akin to a burial place. Duchits and Lobač emphasize that "in a broader sense valley as a low-lying land is correlated in people's views with the grave" (2011: 139-140). Naturally, in this context it is the location of personalized death: "A pajdu ja luham-dalinaju, siadzić smierć pad kalinaju" (And I will go to the meadow-valley, death sits under the viburnum) (Fiadosik 1984: № 197). The center where key events happen is the mountain. In Belarusian folk song lyrics, such natural objects as a mountain, a river, the Danube, and the wellspring are associated primarily with the motif of meeting, the courting of lovers.

Among cultural objects the most semiotically loaded images are garden, road, yard, and house, and their component parts (window, door, pantry, porch, etc.). The image of the garden represents a native house or family, which marries off a girl: "A ŭ sadzie, sadzie ziaziulia kukavala, pa mnie, maladoj, matulia biedavala. - Pakiń, pierastań, ziaziulia, kukavaci, pakiń, pierastań, matulia, biedavaci. Pakiń, pierastań, matulia, biedavaci - ja navučylasia, jak hora haravaci" (And in the garden, in the garden the cuckoo cuckooed. For me, a young girl, Mom is missing. - Stop it, stop it, cuckoo. Stop it, stop it, Mom. Stop it, stop it, Mom - I've known sorrow) (Fiadosik 1984: № 479). Often, a married woman turns into a bird and flies to the native garden to her parents for a piece of advice. In the garden the cuckoo, nightingale, bird, girl, Cossack, father and mother, my brother and sister, flowers, cherries, apples, and grapes are located. The main epithets that characterize the image of the garden are green and cherry, emphasizing positive aspects of this locus. As rightly pointed out by Šved (2011: 197-198), "the permanent epithet green ... has sustained a positive, life-affirming semantics and is perceived not as the color but condition of the tree". Meetings and secret conversations are related to the image of the garden. This image has some characteristics of the alien world: here are located the viburnum or the grave; it is also a part of the associative complex field - the sea-forest-garden, which refers to the spatial borderland.

The image of road has the most distinct characteristics of the borderland in songs. The lexeme road is synonymous to path, track or trail-track. The opposite to road (on the basis of flat/bumpy) is a bumpy track and on the basis of cultivated/natural - harvested cropfield. 
The lexeme road is often the subject of action: knocking, eating, and moaning indicate the dynamic characteristic of the image. However, it can also be the object of the action: to ask for, to go to, to know, to shorten, to glance at, to wait for, etc. But more often it is the place in which certain actions occur: to go on, to keep on, to grow over (grass, birch, oak, aspen), to hang (green viburnum), to go on, to cover up, to plow, to bury on, to roll, (not) to stray from, to find, to tire, to water, to bring to, to throw on, to look for, to come, to spend the night in, to run along.

All characters in the songs are connected with this image: for the girl it is a road to marriage, to the husband's family, to a foster home; for the man it is a road to a foreign land, to Ukraine, to Odessa; for the married woman it is a road to her parental home; for the husband - to Ukraine, to war; for the recruit - to military service; for soldiers (Cossacks, Hussars) - to war, to an alien world; for the Chumak - to Crimea. The road has a fateful role and emphasizes an intermediate state for the characters that stay on it. For example, the behavior of the horse on the road predicts the future fate of its owner:

Vypraŭliala maci syna

U balyšuju darohu.

- Jedź, jedź, moj synočak,

Dy nazad viarnisia.

- A boh znaje, boh viedaje,

Nazad ci viarnusia:

Siarod dvara šyrokaha

Moj koń spatyknuŭsia. [...]

- Kali, kali, moj synočak,

Pryjdzie ka mnie ŭ hosci?

- Tady, tady, maja mamka,

Pryjdu k tabie ŭ hosci,

Jak vyrascie travičačka

$\mathrm{Na}$ novym pamoscie.

Rasla, rasla travičačka

- Stala pasychaci.

Stala jaho mamka časta

Syna ŭspaminaci.

Liacieŭ piatuch cieraz reku,

Kryknuŭ ku-ka-re-ku.

Nie ŭvidziela maci syna,

Nie üvidzić davieku.

(Hilievič 1976: 64-65)
Mother sent her son

on a long journey.

- Go, go, my son,

and come back.

- Only God knows, God knows, if I will come back or not:

in the wide courtyard

my horse stumbled [...]

- When, when, my son,

will you come to visit me?

- My mother,

I'll come to you to visit

when the grass grows

on the new ground.

The grass grew and grew

- and became dry.

Mother recalls

her son every day.

The rooster flew over the river, called 'Ku-ka-re-ku'.

You have not seen, Mother, your son, you haven't seen him. 
Transfer to a distant country, a foreign land is a "great" way, which can be correlated with the path to the other world. Parental instruction precedes the departure. In Belarusian folk song lyrics, the image of the road is tragic, permeated by feelings of bitterness and despair, indicated by the epithets steep, broken, not passing, littered, bad, broken by stone, drenched with tears, soldier, knocking, stony, wide, smooth, brotherly.

The image of the road is semantically related to the place where events happen: "Prajšoŭ ja sviet, Ukrainu - Nie vidzieŭ dziva nad kalinu, Što ŭ luzie pry darozie staić: Na jej vieciejki biez vietru šumiać, Na jej jahadki biez sonca spiejuć, Na jej rasica biez doždžu staić" (I travelled all the world and Ukraine and didn't see such a miracle as the viburnum that stands in the meadow on the roadside: its branches make sound without wind, its berries ripen without the sun, there is dew without rain) (Hilievič 1976: 286); or an interval, connecting the points of the space: "Biažy, kosiu, darohaju, Biažy, kosiu, šyrokaju - Na try stupy stupajučy, Svajho domu šukajučy” (Run, horse, along the road, by the wide path, and there will be an old house) (Hilievič 1976: 74). Also this image semantically represents a "way of life", personal destiny, or fate.

The time of day in which the character walks is very important: the road at nighttime is perceived as very dangerous because it is the period of activity of evil forces. Lobač emphasizes that "one and the same road is not equal in the daytime and at night, in the field, forest, swamp, near the temple, cemetery, and inn, and especially in nodal points of its deployment - on the bridge, causeway or at a crossroads" (2013: 322).

The lexeme is characterized by compatibility with the numbers two and three. Overgrowing, sweeping, and covering the road symbolize obstacles that the hero cannot overcome:

- Jak mnie, braciejko, jak mnie, rodnieńki,

U hasciach ŭ vas byvaci?

Pazarastali sciežki-darožki

- Nie mahu prataptaci.

- Najmi, siastryca, najmi, rodnieńka,

Skrypki, cymbaly,

Kab prataptali sciežki-darožki

Da zialionaha haju.

(Hilievič 1976: 20)

- How can I, my brother, how can I, my dear, visit you?

The path-track grows over, I can't trample.

- Hire, sister, hire, my dear, a violin,

a dulcimer to trample the road to the green grove. 
The expression to throw the road means to prevent, stop an action:

- Zdrada, zdrada, čornieńkija broŭcy,

Oj, niavierny milieńkaha sloŭcy.

Jak liubiŭsia - žanicca maniŭsia,

A ciapier jon mianie pakidaić,

$Z$ nočy-poŭnačy kaniu abrok dajeć,

Rana-ranieńka $z$ dvoru vyjazdžaić.

- Nie jedź, nie jedź, moj milieńki,

liesam Pazakidaju darohu vierasam.

Nie jedź, nie jedź, moj milieńki boram

- Pazakidaju darohu javoram.

(Hilievič 1976: 112)

- Treason, dark eyebrows, treason, my dear, your words were untrue. When he loved me

- he deceived to marry, and now he leaves me alone at night.

He gives oats to the horse early in the morning and leaves the yard.

- Don't go, don't go, my dear, by the forest road,

I will throw the road by heather.

Don't go, don't go, my dear, by the forest road

- I throw the road by sycamore.

The image of bridge is semantically connected to the location of the boundary. The expression going over the bridge has gained the metaphorical meaning of losing virginity.

The center of a cultivated area is a house, where the main characters (girl, wife, mother, daughter, stepmother, husband, drunkards, children, boyfriend, oat and rye bread) are located. In lyrical songs the house is a part of the yard, but it includes the smaller parts such as the window, door, and porch; there are also outbuildings - a barn and others. The lexeme house is semantically related to a safe locus, acts as a resting place, and is in constant contact with the holidays: "Da ja ž doma byvala, Časta piva pivala. Siastra pje, z rotu ĺje, Bratka pje - z kania mlieje, Jak napiŭsia, dyk zvaliŭsia" (And I visited home and often drank a lot of beer. Sister drank, beer poured out of her mouth. Brother drank, the horse was thrilled, he drank and fell from the horse) (Hilievič 1976: 173).

The house as a safe locus is opposed to danger - war: "- Tabie, synočak, tabie: Ty ž na vajnu pajedziš, A nas doma pakiniš. - Nie plač, mamka, pry mnie, Naplačyšsia biez mianie. Naplačyšsia davoli, Jak nie ǔvidziš nikoli” (You, my son, you: You will go to war and leave us at home. - Do not cry, my dear mom, when I'm here, you will cry without me, you will cry enough, when you would 
have ever seen me) (Hilievič 1976: 60). Staying at home is opposed to freedom and festivities that are associated with a violation of social norms (loss of virginity outside of marriage), and, in the end, lead to undesirable consequences. The image of a house is also opposed to the surrounding world. In combination with the attributes eternal, cramped, and dark the lexeme house acquires the opposite meaning - a coffin, is characterized by the absence of the typical features (windows, doors), and is located opposite to the sun: "A kali ž dy pamru Staliaročkaŭ ja syšču, Jalinu rubać skažu. Buduć jalinu rubać, Viečny dom budavać - Biez dzviarej, biez akonca, Proci jasnaha sonca" (And when I will die, and I will find woodworkers, I will tell them to cut down the spruce. They will cut down the spruce to build the eternal house - without doors, without windows, against the bright sun) (Hilievič 1976: 74).

The expression state house means prison. In this meaning it acts as a synonym to the lexeme captivity. Staying in a state building relates to an unhappy fate. Often images of a young man or husband are linked with absence and leaving home (the opposite of home is a distant world). Life in a husband's family that is located far away (beyond the Danube) is in opposition to the native home: "Za Dunajem staić chatačka, A tam žyvie maja matačka, Oj, tam žyvie maja rodnaja. Ja ad mamački adlučylasia, Da sviakroǔki prylučylasia" (Behind the Danube my home is and there my mother lives, oh, there my dear lives. I left Mom and joined mother-in-law) (Hilievič 1976: 213).

The aim of banishment from home is to get rid of the character. Lobač emphasizes that "the forced removal (banishment) from the house of one of the family (especially parents who embodied the continuity between generations) leads to tragic consequences for the whole family" (2013: 289): “A ŭ poli krapiŭka žyžlivaja, Ǔ niaviechny sviakroǔka žurlivaja. Žuryla niaviechnu jak dzień, dyk noč, Vyhnala niaviechnu z domu proč: - Idzi, niaviechna, u čysta polie, A stań ža ty tam rabinaju, Rabinkaju zielianieńkaju" (Stinging nettle is in the field, the daughter-in-law has a sad mother-in-law. She screams at her daughter day and night, and kicked the daughter out of the house: - Come, daughter, in the open country, stand there, rowan tree, green rowan tree) (Hilievič 1976: 286).

The lexeme house is not a subject of action but, as a rule, it is in a dependent position. The main activities related to the house can be divided into several groups: staying in the house (presence/absence: (not) to stay, to spend the night, (not) to find); meals, drinks (to have dinner, to drink (beer)); rest (to sleep), work (to flail); directional movement (to go with, to expel, to leave); other actions (to happen (trouble), to give birth to, to love, to brew (beer)).

The exterior of the house, according to the lyrics, is a mirror of family life. "Disorder" in its exterior indicates the general situation in the family: 
- Čaho ŭ ciabie, siastryca, chatka niaroŭna?

Čaho ŭ ciabie, siastryca, parohi vysoki?

Čaho ŭ ciabie, siastryca, vadzica dalioka?

- Cišej, braciejka, cišej havary.

Ty ž maju sviakroŭku nie unaravi.

Ty ž maje chatački nie paraŭnuješ,

Ty ž maich parohaŭ nie panižaješ.

Ty ž majoj vadzicy nie nabližaješ,

Ty ž majoj sviakroŭki nie zadobryš.

(Hilievič 1976: 190)

- Why is, sister, your house uneven?

Why does, sister, your house have high thresholds?

Why is, sister, water so far?

- Hush, brother, speak softly.

Don't make my mother-in-law angry!

You won't even my house, you don't put down my thresholds.

You don't bring my water closer,

you aren't to make my mother-in-law kind.

The order, respectively, points at peace and harmony: "Čamu ž mnie nie pieć, Čamu ž nie hudzieć, Kali ǔ majoj chatačcy Paradak idzieć?” (So why shouldn't I sing, shouldn't I buzz, if my house is in order?) (Hilievič 1976: 296).

A component part of the house - the window - receives sufficient semiotic load. The lexeme is semantically the place of communication with the outside world:

Chadzila udovačka u dalinku,

Prakalola nožačku na bylinku.

Padyšla k dzievierku pad akienca.

- Paradź mnie, dzievierka, dzie mnie dziecca?

- Radžu, bratovačka, isci ŭtapicca,

$Z$ malieńkimi dzietkami nie vadzicca.

Pajšla jana k bracietku pad akienca.

- Paradź mnie, bracietka, dzie mnie dziecca?

A radziŭ mnie dzievierka utapicca,

$Z$ malieńkimi dzietkami nie vadzicca.

- Nie tapisia, siastryca, nie tapisia,

Pryjdzi ŭ maju chatačku, prychinisia,

$Z$ malieńkimi dzietkami pavadzisia.

(Hilievič 1976: 26) 
The widow went to the valley, pierced her foot on the grass.

She went to her brother-in-law under the window.

- Give me a piece of advice, brother-in-law, where should I go?

- I advise you, brother's wife, go away and drown, don't stay with small children.

She went to her brother under the window.

- Give me a piece of advice, brother, where should I go?

The brother-in-law advised me to drown, not to stay with small children.

- Don't drown, my sister, don't drown, come to my home, get some rest, and play with small children.

Baiburin (2005 [1983]: 166) noted that windows and doors "are related to the idea of penetration, connecting the house with the outside world, but this connection has a specific character. Windows connect houses not only with the rest of the world, but with the world of cosmic phenomena and processes, such as the sun (moon), the part of the world, the landscape, the alternation of light and darkness, day and night, winter and summer, etc.".

The Ukrainian and Russian toponyms (Ukraine, Crimea, Rus, Moscow) in Belarusian folk songs lyrics, as a rule, semantically represent a foreign country that is characterized by remoteness and an exceptional degree of danger; there a hero expected an unhappy fate, illness, and even death. However, they can be marked neutrally, as the location of the Cossack, soldier, or recruit. Motifs of deception, treason, loss of virginity, and a bastard child are connected with these characters. Metropolises (Kyiv, Lviv, Warsaw, Cracow) are otherwise semantically important: they represent cultural centers and the center of the universe.

A man inhabits the central place in the worldview in Belarusian folk song lyrics. The image of a man, as a rule, is characterized by the emotional and evaluative adjectives lazy and nice. The image is determined not only by the presence of body parts, organs, or fluids (head, eyes, lips, face, hair, eyebrows, arms, hands, feet, blood, flesh, bones), but also by the soul and mind. The lexeme body is usually used when talking about a killed/wounded young man/soldier: "Tam liažyć pad kustom ciela bielaje, ciela bielaje, to saldackaje. Maladzieńki saldat uvieś paranieny, pierad smierciu liažyć, jak plast bielieńki” (There under the bush the white body lies, the white body of the soldier. The young soldier was wounded whole, white before death) (Kabašnikaŭ et al. 1985: 482). The lexeme is accompanied by the epithet white and, depending on the object, is semantically reflective of clean, young, or beautiful (if characterizing female 
characters): “Oj, addavala mianie mamačka, Za kaho ja nie chaciela. Oj, šumić, hudzie da j nahaječka Lia majho bielaha ciela" (Oh, Mom married me to whom I didn't want. Oh, whip noises, buzz near my white body) (Hilievič 1976: 226) or bled white (if related to a soldier/Cossack): "Liažyć ciela, jak dzień, biela, biez ruk, biez noh, biez haloŭki" (Lies the body as day, white, with no arms, no legs, no head) (Šyrma 1960: 300). The epithets killed and soldier (severely wounded soldier) also characterize it as lifeless. Images of body parts are symbols of abstract concepts: head - mind, heart - emotions, face, eyes, and eyebrows beauty, youth. The braid serves as indicator of willingness/unwillingness to marry, shoulders is an object of physical impact. Associative complexes soul body, soul - heart represent the whole person.

A significant part of lyrical songs focus on questions of personal fate. According to the songs, destiny is given to a person in a key moment - at the moment of birth. Mother or God endows a man's personal fate. At the same time Belarusian lyrical songs indicate that fate depends on godfathers. The fate is given by "higher powers" and does not depend on external factors (desires, behavior, appearance, etc.). However, a fairly common plot is that the fate of the person is taken regardless of the will of God: "Što ž ty, matka, što ž ty, matka, narabila, čamu rana nie zbudzila? Usie dzievački, usie dzievački rana ǔstali, ščascie j doliu razabrali. Ja, malada, ja, malada, spaznilasia, ščascia j doli ŭmylilasia” (What did you, Mother, do, why didn't wake up early? All the girls, all the girls got up early, and took good fortune. I was, I was late, and happiness and good fortune didn't receive) (Šyrma 1960: 7). The song emphasizes that personal fate is only a certain portion of overall fate.

In Belarusian folk song lyrics, destiny is not absolute: the turning point is the wedding: “- Z doliaju radzila, z ščasciem hadavala, jak papaŭsia lichi zamuž, navieki prapala" (I gave you birth with good fortune, you grew up with happiness. You married unsuccessfully, and lost happiness forever) (Šyrma 1960: 151). Baiburin explains that "a person receives the fate at the moment of birth, but at the same time in next rituals ... new destiny or rather additional is necessary for a new stage of life" (1993: 122). The conception of good destiny is directly linked to successful marriage, creation of family, mutual love: "Nie tam ščascie, nie tam dolia, dzie bahaty liudzi, a chto biare pa milosci, toj ščaslivy budzie" (There is no happiness, it is no good destiny where rich people are, but who marries for love, that one would be happy) (Fiadosik 1978: 156).

Unfortunate fate is related to a husband's family: "Doliečka lichaja - siamiejka čužaja" (Unfortunate fate - other family) (Šyrma 1960: 60). The fate of married women appears unchanged; it is already impossible to overcome: 
Pajdu da kamory - ani chlieba, ni soli.

Ni ŭciakaci mnie, ni ǔbiažaci mnie ad nieščaslivaj doli.

Pajdu da matuli, na paroh pastupliusia.

Liudzi havorać, ja j sama znaju, što nazad nie viarnusia.

(Šyrma 1960: 30)

I'll go to the pantry - neither bread nor salt.

I can't run, can't run from my unhappy fate.

Go to your mother, tread on the threshold.

People say and I know myself that I'll not come back.

Unhappy destiny is also linked to the absence of family, the inability to marry the loved one, recruiting, service in the army, and inability to earn money. The fate of orphans and widows is shown as particularly unfortunate. The nouns fate and destiny are accompanied by metaphorical epithets: "Oj, horkaja ja i dolia maja, za pjanicu zamuž vyjšla" (Oh, I'm bitter and my fate is bitter, I've married a drunkard) (Kabašnikaŭ et al. 1985: 499). Genetically related to the mythological way of thinking, metaphorical epithets emphasize a particular role of the concept in songs, giving them emotional coloring.

The image of destiny often has anthropomorphic, personalized features:

Oj, viadu biadu, oj, viadu biadu, dy biada nie viadziecca.

A pad višniaju, pad čarešniaju biada spaci kladziecca.

Oj, liažy, biada, dy zasni, biada,

na ŭsiu nočańku spaci,

a ja, molada-maladziusieńka, pajdu mila šukaci.

(Fiadosik 1978: 144)

Oh, I lead trouble, oh, I lead trouble,

but the trouble is not led.

Under a cherry, under a sweet cherry trouble is going to bed.

Oh, lie down, trouble, go to sleep, trouble,

sleep the whole night, and I, a young girl,

am going to look for a loved young man.

It can also be embodied in images of plants (shrubs, flowers, grasses) or any other material object.

A significant place in the image system of Belarusian folk song lyrics is occupied by animalistic images (images of birds, animals, and fish). They represent gender and age affiliation as well as the social status of characters, and present the ideal relationship between two lovers. Images of animals perform mediator functions. In song lyrics images of birds are used to emphasize the 
similarities/differences in age and social status. Images with clear female semantics stand out: the swallow symbolizes a woman of premarital age, a wife, a mother, a sister; the cuckoo - a wife that is missing a husband, a mother that worries about the fate of her daughter in another family, an orphan; the female dove - a girl, woman, or mother. A number of bird images are constantly semantically male: the male dove symbolizes an unmarried male, a brother; the nightingale - a man, Cossack, brother, husband, father-in-law; the falcona successful, clever, brave guy, father, brother, or guest, as well as a destroyer or fighter; geese symbolize young recruits. The daw can act as a female and as a male image. Paired ornithological images symbolize mutual love, faithfulness, sincerity, harmony, mutual respect, and an ideal relationship between two lovers: "Zažyviom my, zapanujem, jak halubkoŭ dvoje, i razdzielim z taboj ščascie, doliu j niadoliu" (We will live, will reign, as two doves, and share with you happiness and unhappiness) (Kabašnikaŭ et al. 1985: 512). Such birds as the cuckoo, pigeon, falcon, and nightingale as well as geese in Belarusian folk song lyrics are messengers between a girl and her native home, parents, and relatives; between lovers; between a soldier of war and his mother or wife: "Pa siastruliečku šliu ziaziuliečku, A pa ciotačku - pierapiolačku, A pa bratačku salavieječku..." (For my sister I send a cuckoo, for my aunt a quail, but for my brother a nightingale...) (Hilievič 1976: 236).

Birds are the inhabitants of the upper circle of the universe, which know and see everything. They report the unhappy fate of the girl in another family and bring news about the death of the young man at war in a foreign land. A frequent motif is a woman turning into a bird - cuckoo: the girl transforms and flies to the parental home or a garden; the mother flies and searches for her son in a foreign land:

- Kab ja byla ziaziulkaju, umiela kuvaci, paliaciela b na Ǔkrainu synočka šukaci.

Paliaciela b na Ukrainu i skazala b:

- Ku-ku! - Padaj, padaj, moj synočku, choć pravuju ruku!

- Oj, rad by ja, maja maci, abiedzvie padaci,

- syra ziamlia, smoĺna doška - ciažańka ŭstaci.

(Šyrma 1959: № 204)

- If I were a cuckoo, I could cuckoo!

I'd fly to Ukraine to look for my son.

I'd fly to Ukraine and would say:

- Cuckoo! - Give, give, my son, to me the right hand!

- Oh, I'm glad to give you, my mother, both,

but - damp land, board in the resin - it's hard to stand up. 
Eremina shows that this motif is a testament to the belief in transformation and conveys to us the remains of mythological thinking. "Mythic consciousness over time loses the basic elements of its content (the belief in a universal spirituality, in conversion, etc.), but the form of expression of aesthetic value ideas remains almost untouched, it is only slightly modified, and therefore lives for centuries," she explains (Eremina 1978: 27).

Images of domestic animals (ox, cow, horse) are widely presented. The image of a horse has the most semiotic load among them. The horse (an essential attribute of a young man, Cossack, soldier, or brother) is the main means of movement. This image symbolizes the faithful companion, helper, or friend. Buying a horse is directly connected with departure to war: “- Oj, kamu ž ty, ajčeńka, kupliaješ kaničeńka i tak siĺnieńka plačaš? - Dlia ciabie, moj synočku, pajedzieš na vajnočku, na čužuju staronu" (Oh, to whom do you, Dad, buy a horse and are crying for so much? - For you, my son, you will go to war in another land) (Fiadosik 1987: № 54). The horse receives the mandate to report to relatives about the death of a soldier, recruit, Cossack, or a young man at war:

- Oj ty, koń, ty, moj koń, koń, tavaryšak moj, zaniasi,

ty moj koń, ajcu, maciery paklon.

Nie skažy ž ty, moj koń, što ja ŭbity liažu,

a skažy ž ty, moj koń, što žanaty chadžu.

Ažanila mianie kulia bystraja, abviančala mianie šablia vojstraja.

(Fiadosik 1987: № 249)

- Oh, you, the horse, you, my horse, the horse, my friend, bring reverence, my horse, to my father and mother.

Do not tell, my horse, that I am lying dead

but tell, my horse, that I got married.

I was married to a fast bullet, I was married to a sharp sword.

The horse (or horses and oxen, horses and cows, which form association complexes) also serves as an indicator of well-being, wealth, and prosperity: "Choć ty sabie znojdzieš z kaniom i z valami, a taki nie znojdzieš z čornymi bryvami..." (Even though you find a girl with a horse and oxen, you will not find a girl with black eyebrows...) (Šyrma 1959: № 20).

The image of the fish symbolizes the girl: "Dziaǔčynačka, maja rybka, nie plač, nie tužysia..." (Girl, my fish, don't cry, don't be offended...) (Fiadosik 2005: № 167). A pair of fishes - the roach and the perch - semantically reflects an ideal relationship between two lovers. Parting with a girl is also as unnatural as the separation of fish with water, or roach and perch.

A significant place in the image system belongs to floral (plant) images. Floral (plant) images are used to indicate gender (birch, willow, viburnum, mountain 
ash, apple, cherry, spruce, pine, rose, etc. symbolize a woman; sycamore, oak, knapweed, wormwood, hops, etc. - a man). In the social lyrics, some traditionally female images (apple, spruce) are used to refer to male characters, due to the specificity of the genre type. Birch, viburnum, willow, rowan, spruce, pine, cherry, sycamore, and oak mark the place where emblematic events happen: a meeting of lovers, loss of virginity, a soldier's death. Female dendrological images - cherry, birch, cranberry, raspberry, apple - represent beauty, attractiveness, and youth. Pairs of trees in songs are examples of the ideal relationship between lovers.

Floral (plant) images are also mediators between our own and the alien world (a potion) and correlate with the lower circle of the universe (grass). Grain crops (rye, wheat, barley, etc.) form association complexes and act as an undivided whole. Viburnum, pine, cherry, and tarragon are in constant communication with the concept of an unhappy fate or obstacle. Growing over trees/bushes / grass represents obstacles, an impossible meeting, or a return to the parental home. The images of the rue, rue-mint, and rue wreath are semantically related to virginity. Coded in the expressions trample rue and feed the horse in the rue are situations connected with the sphere of intimate relations.

In Belarusian folk songs lyrics weather images are widespread. The image of frost semantically reflects obstacles and difficulties: "Oj, za liutymi za marozami Ruta-miata nie ŭschodzić. A za liudskimi nahavorkami Ka mnie mily nie chodzič" (Oh, because of the fierce frost the mint doesn't rise. And because of people's gossip my dear doesn't visit me) (Hilievič 1976: 110). In this case, the lexeme is used with the epithet fierce, which emphasizes an irresistible force. The absence of frost, respectively, indicates a carefree life: “Oj, zieliena, zieliena u luzie trava. Čamu jana zieliena? Marozu niama. Oj, molada, molada u muža žana. Čamu jana molada? Bo dolia ladna" (Oh, green, green grass is on the meadow. Why is it green? There is no frost. Oh, the husband has a young, young wife. Why is she so young? Because her fate is so lucky) (Hilievič 1976: 210).

Opposite to fierce frost as cold, is a white bed that represents home, warmth, and rest. The advent of the frost semantically represents the end of free life, being recruited. Opposite to the dew is the frost. In general, in lyrical songs the lexeme dew occurs precisely in the context associated with walking barefoot. The semantics of bare feet is directly linked to the sphere of intimate relations, and the dew is linked with the male sphere. Valodzina and Vuhlik emphasize that acts of putting on shoes or trampling have a certain erotic function and become metaphors of the act of fertilization (2011: 326).

The image of wind characterizes activity and dynamism, as indicated by the frequent use of the lexeme as the subject of an action. Its semantics has a relationship with a harmful effect or prevention, as indicated by the verbs to 
blow, to break, to twist, to break off, to break up, to lift, etc. The image of wind referred to at the beginning of the song does not portend a happy solution, but rather points to a certain complexity - an unhappy family life, fate; a bastard child; going into the army, service in the army; gossip. This image also semantically reflects a messenger that reports news. In Belarusian folk song lyrics wind acts as a cause of waves that fill the boat with a heroine, which indicates its destructive nature. A husband compared with the wind emphasizes his difficult character. The image of rain is used for a sketch of the overall picture, describing the weather, during which the plot unfolds. A miracle is often described as something that takes place without the participation of nature forces. Another common meteorological image is the fog. This image usually takes a semantically marked position - at the beginning, and indicates the tragic denouement of the plot. The lexeme fog is opposite to the sun - an analogue of the upper circle of the universe. This image is semantically related to obstacles. The image of a cloud typically used at the end of the song, when lovers part, is associated with the divergence of black/dark clouds. A black cloud forms an associative complex with dark/human glory: “- Dziaǔčynańka mila, Čym budzieš ukryvacca Na Ǔkrainie daliokaj? - Ciabie ǔkryje čorna chmara, Mianie ǔkryje ciomna slava Na Ǔkrainie daliokaj" (- Dear girl, what will you be covered with in distant Ukraine? - You will be covered by the black cloud, I will be covered by dark glory in distant Ukraine) (Hilievič 1976: 110).

Gastronomic elements are also associated with the encoding of intimate relationships (to eat fish, to sup on fish). Gastronomic images relate to the motifs of loss of virginity, unhappy fate, verifying the human qualities of the lyrical heroine. The use of magic potion is a transition from the "alien" world to "our" world and vice versa. The associative complex bread - salt symbolizes prosperity.

Numbers also take an important place in the songs. The number three has a sacred characteristic and is used to describe "reality": it refers to the triad of characters, which are realized through the representation of the three-circle universe; highlights the particular character; and indicates time, place, action, the number of objects or phenomena, etc., which are central to the plot. The number three is a significant compositional principle, the essence of which is found in the triple repetition of similar designs. The number two is used for pairing, which is implemented in the images of a pair of lovers, spouses, two brothers, sisters, friends, or young men. The number four is related to the formula three - the fourth, by which the value of completeness is passed. The number seven is related to the performance of certain actions; it means "many" or denotes the border or age of consent. In some contexts, the numbers three and seven act interchangeably. Forty is semantically significant as a time interval, which is given to man for the final transition to the world of people, and corresponds to the concept of "a long time". 


\section{CONCLUSIONS}

The aim of the article was to show the worldview of Belarusian folk song lyrics. In folk songs the world - a specific, limited space which is inhabited by people is formed by heaven and earth. The world is oriented vertically (top - bottom) and horizontally (east - west).

In folk song lyrics the earth is the epitome of femininity (expressions such as earth-mother). The associative complex damp land-yellow sand is semantically related to the grave. The heaven is the "mirror" of the most important, significant events on the ground. In a small group of songs heaven is the place of God's location.

The man with his private destiny has a central place in the worldview of folk song lyrics. In songs the image of a man is determined not only by the presence of body parts, organs, and fluids (head, eyes, lips, face, hair, eyebrows, arms, hands, feet, blood, flesh, bones) but also the soul and mind. Fate "is given" at the moment of birth by the mother/God and it accompanies the lyrical hero throughout life, but it can be changed in the transition to a new stage of life or by personal volition, so the destiny is not absolute. Personal destiny acts as a personalized concept in Belarusian folk song lyrics.

The lower circle of the universe strongly correlates with valley, grave, and grass, and the upper - with mountain, sun, moon, and stars. Mediators between the "alien" and "our" space are a bird and a horse. The image of the garden symbolizes "our" space, whereas Ukraine, Crimea, etc. symbolize the "alien" one. Such images as grove, road, tree, forest, sea, bridge, the river, the Danube, etc. reflect distinct spatial characteristics of the borderland. In the "foreign" territory is grass, a cranberry, a Cossack (deceased), two young men (injured), a Chumak, a soldier, a horse, a grave, death, fog, a wellspring, etc. Images of birds, a cuckoo, a nightingale, two nightingales, a peacock, a lady, a Cossack, daddy, mummy, sister and brother, a flower, berries, cherries (berries), an apple, a pear, a grape, sugar snap peas, sugar gooseberries, flowers, a lily, a blue flower, a one-year flower, pink flowers, a pink flower, a herb, a root, mint, hops, leaves, spring, a bed, a house, etc. are associates with "our" space. At the same time the boundaries between them are moving and depend on the action of binary oppositions.

Images of the same group have their own meaning sphere and perform specific functions. Individual characteristics depend on the species of the genre of Belarusian folk song lyrics. Astronomical images are semantically associated with the sphere of kinship: sun - mother, girl, father, an old man; moon - father, star - daughter, mother, sister. Time is also encoded in astronomical images. Sunset, the appearance of stars in the sky, moonrise and stars indicate the onset of the dark time of the day (evening, night); sunrise indicates the dawn; bright 
sun indicates the daytime or day. Violation of the primordial order indicates the presence of a specific problem, description/decision in which the plot of the song consists. Calendar-chronological images are semantically connected with regulation of work and rest. The appropriate time of the day (day), days of the week (Monday, Tuesday, Wednesday, Thursday, Friday, Saturday), and seasons of the year (spring, summer) are intended for work. Night, Sunday, and winter are intended for rest. Sunday has a special semiotic loading in Belarusian folk song lyrics. Transitional ceremonies (birth, marriage, death, as well as being recruited, meeting with God, an illness) are connected with it. Landscape-topographical images mark "our" territory, a symbolic place, the center, where events significant for a song happened; they act as a boundary locus, and represent the "alien" world. Plant images are used to indicate the sex and age of characters and designate the place where the emblematic event happened. Animalistic images represent sex-age affiliation, the social status of lyrical heroes, and the ideal relationship between two lovers. Images of animals are mediators between "our" and the "alien" space. Somatic elements - head, shoulders, hands, foot, face, hair, tress, lips, eyes, eyebrows, body - represent the man in Belarusian folk song lyrics. Body parts are symbols of certain abstract concepts: head - mind; heart - feelings; face, eyes and eyebrows - beauty, youth, and are the objects of physical pressure. The concept of the body is used to designate a dead/injured man. Meteorological images are semantically related to obstacles and correspond with the motifs of an unhappy fate, being recruited, loss of virginity, or a bastard child. Gastronomic images are indicators of prosperity and used to refer to sexual relations; semantically represent the loss of virginity or unhappy fate; are used in the sense of checking the moral and ethical qualities of women, and indicate the transition from an alien world to our own or vice versa. Numbers are used to indicate the number of characters; to highlight the particular character/object; to indicate time, place, and action or the number of objects, phenomena, etc., which are central to the story. In some contexts, in song lyrics numbers are interchangeable.

\section{ACKNOWLEDGEMENTS}

The article was written as part of a project financed by the Foreign Ministry of Estonia through the Developmental Cooperation Programme (66-2015-A).

\section{NOTES}

1 By Tsivyan's definition (1990: 5), a picture of the world, projected to a specific genre of folklore, is "a shortened and simplified reflection of the entire amount of ideas about the world in this tradition, taken in their systemic and operational aspects". 


\section{REFERENCES}

Baiburin, Al'bert 1993. Ritual v traditsionnoi kul'ture: strukturno-semanticheskii analiz vostochnoslavianskikh obriadov. [The Ritual in the Traditional Culture: Structural and Semantic Analysis of the East Slavic Rites.] St. Petersburg: Nauka.

Baiburin, Al'bert 2005 [1983]. Zhilishche $v$ obriadakh i predstavleniiakh vostochnykh slavian. [Dwelling in the Rites and Beliefs of the Eastern Slavs.] Moscow: Iazyki slavianskoi kul'tury.

Bulgakovskiy, Dmitriy 1890. Pinchuki: Etnograficheskii sbornik. [Pinchuki: Ethnographic Collection.] St. Petersburg: Tipografiia V. Bezobrazova i Komp. Available at http:// www.bookva.org/books/74, last accessed on 26 April 2018.

Citovič, Hienadź 1975. Antalohija bielaruskaj narodnaj piesni. [Anthology of Belarusian Folk Songs.] Minsk: Bielaruś.

Citovič, Hienadź 1959. Piesni bielaruskaha naroda: Vybranaje. [Songs of the Belarusian People: Favorites.] Minsk: n.p.

Čurkin, Míkalay 1949. Bielaruskija narodnyja piesni i tancy: muz.-fal'kl. zb. [Belarusian Folk Songs and Dances: A Musical and Folklore Collection.] Mínsk: Dzyarzh. Vyd-va BSSR. Red. muz. lít.

Czeczot, Jan 1844. Piosnki wieśniacze z nad Niemna i Dźwiny, z dołaczeniem pierwotwornych $w$ mowie stawiano-krewickiéj. [Peasant Songs from the Niemen and Dvina Rivers.] Wilno: Druk. J. Zawadzkiego. Available at http://www.dbc.wroc. $\mathrm{pl} /$ dlibra/doccontent?id=6883, last accessed on 26 April 2018.

Czeczot, Jan 1846. Piosnki wieśniacze z nad Niemna i Dźwiny, niektóre przystowia i idiotyzmy, w mowie stawiano-krewickiej, s postrzeżeniami nad nia uczynionemi. [Peasant Songs from the Niemen and Dvina Rivers.] Wilno: Druk. J. Zawadzkiego. Available at http://www.dbc.wroc.pl/dlibra/doccontent?id=6887, last accessed on 26 April 2018.

Dobrovol'skiy, Vladimir 1903. Smolenskii etnograficheskii sbornik. [Smolensk Ethnographic Collection.] Vol. 4. St. Petersburg: Tip. V.Vasil'yeva.

Duchits, Lyudmila \& Lobač, Uladzimir 2011. Dalina. [Valley.] Mifalohija bielarusaŭ. [Mythology of Belarusians.] Minsk: Belarus, pp. 139-140.

Eremina, Valeria 1978. Poeticheskii stroi russkoi narodnoi liriki. [Poetic Structure of Russian Folk Poetry.] St. Petersburg: Nauka.

Federowski, Michał 1958. Lud biatoruski na Rusi Litewskiej. [The People of Belarus in Rus Lithuania.] Vol. 5: Pieśni. [Songs.] Kraków \& Warszawa: Państw. Wydaw. Nauk.

Federowski, Michał 1960. Lud biatoruski na Rusi Litewskiej. [The People of Belarus in Rus Lithuania.] Vol. 6: Pieśni. [Songs.] Kraków \& Warszawa: Państw. Wydaw. Nauk.

Federowski, Michał 1969. Lud białoruski na Rusi Litewskiej. [The People of Belarus in Rus Lithuania.] Vol. 7: Suplement do t. 5 i 6. [Supplement to Vol. 5 \& Vol. 6.] Kraków \& Warszawa: Państw. Wydaw. Nauk.

Fiadosik, Anatol (ed.) 1978. Piesni pra kachannie. [Love Songs.] Minsk: Navuka i technika.

Fiadosik, Anatol (ed.) 1984. Siamejna-bytavyja piesni. [Family Songs.] Minsk: Navuka i technika.

Fiadosik, Anatol (ed.) 1987. Sacyjaĺna-bytavyja piesni. [Social Songs.] Minsk: Navuka i technika. 
Fiadosik, Anatol (ed.) 2005. Faĺklor u zapisach Jana Čačota i bratoŭ Tyškievičaŭ. [Folklore Written Down by Yan Chechot and the Tyszkiewicz Brothers.] Minsk: Bielaruskaja navuka.

Gil'tebrant, Petr 1866. Sbornik pamiatnikov narodnogo tvorchestva v Severo-Zapadnom krae. [The Collection of Folk Art in the Northwest Territory.] Vil'na: Tipografiia Romma R. M.

Golovacheva, A. V. 1993. Kartina mira i model' mira v pragmatike zagovora. [The Picture and the Model of the World in Pragmatics of Charms.] In: V. Ivanov (ed.) Issledovaniya $v$ oblasti balto-slavyanskoy dukhovnoy kul'tury: Zagovor. [Research in Balto-Slavic Spiritual Culture: Charm.] Moscow: Nauka, pp. 196-211.

Harecki, Maksim \& Jahoraŭ, A. 1928. Narodnyja pieśni z meliodyjami: Zbornik. [Folk Songs with Melodies: Collection.] Minsk: Vyd-va In-tu Bielarus. kuĺtury.

Hilievič, Nil 1968. Naša rodnaja piesnia. [Our Native Song.] Minsk: Nar. asvieta.

Hilievič, Nil 1975. Paetyka bielaruskaj narodnaj liryki: slova i vobraz. Paetyčny sintaksis: Hukapis i ryfma. [Poetics of Belarusian Folk Poetry: Word and Image. The Poetic Syntax: Transcription and Rhyme.] Minsk: Vyš. šk.

Hilievič, Nil (ed.) 1976. Liryčnyja piesni: Bielaruski faĺklor u sučasnyh zapisach. [Lyric Songs.] Minsk: BSU.

Hliebka, Piatro 1975. Pytanni historyi, filalohii, mastactva. [Questions of History, Philology, Art.] Minsk: Navuka i technika.

Hrynblat, Mihail 1967. Sacyjaĺna-bytavaja liryka. [Social Songs.] In: Bielaruskaja narodnaja vusnapaetyčnaja tvorčasć: historyka-tearetyčnae dasliedavanne. [Belarusian Oral Art: Historical and Theoretical Research.] Minsk: Navuka i technika, pp. $167-185$.

Hurski, Anton 2002. Pazaabradavaya paeziya. [Nonceremonial Poetry.] Minsk: Belaruskaja navyka.

Kabašnikaŭ, Kanstancin \& Lis, Arsen \& Fiadosik, Anatol \& Ciščanka, Ivan (eds.) 1985. Bielaruski faĺlor: Chrestamatyja. [Belarusian Folklore: Chrestomathy.] Minsk.

Karskiy, Evfimiy 2007 [1916]. Belorusy: Ocherki slovesnosti belorusskogo plemeni. [Belarusians: Essays on Belarusian Literature.] Vol. 3, B. 1. Minsk: Belorus. Entsikl.

Kolberg, Oskar 1968. Białorus-Polesie. [Belarus-Polesie.] Warszawa: Ludowa Spółdzielnia Wydawnicza.

Kuba, Ludwik 1887. Beloruska pisen. [Belarusian Songs.] Slov. sbornik. [Slavic Collection.] Vol. 4.

Lobač, Uladzimir 2013. Mif. Prastora. Čalaviek: Tradycyjny kuĺturny landšaft bielarusaŭ u siemijatyčnaj pierspiektyvie. [Myth. Space. Man: Belarusians' Traditional Cultural Landscape in a Semiotic Perspective.] Minsk: Tehnalogija.

Mažejka, Zinaida 2008. Piesiennaja Liryka. [Song Lyrics.] In: V. Bialiavina \& M. Pilipienka \& I. Čakvin (eds.) Belarusy. [Belarusians.] Minsk, pp. 119-158.

Nikitina, Serafima 1993. Perspektivy slovaria. [Perspectives of the Dictionary.] In: S. Nikitina. Ustnaya narodnaya kul'tura i yazykovoye soznaniye. [Oral Folk Culture and Language Consciousness.] Available at http://philologos.narod.ru/ nikitina/Part_16.htm, last accessed on 7 May 2018.

Nikitina, Serafima 2006. K probleme sostavleniia slovarei iazyka fol'klora. [On the Problem of Compiling Dictionaries of Folklore Language.] In: A. Kargin (ed.) Pervyi Vserossiiskii kongress fol'kloristov: sbornik dokladov. [First Russian Congress of Folklore: Collection of Papers.] Vol. 2. Moscow: Gos. respublikanskii tsentr russkogo fol'klora, pp. 66-82. 
Radchenko, Zinaida 1881. Sbornik malorusskikh i belorusskikh narodnykh pesen Gomel'skogo uezda, zapisannykh dlia golosa s akkompanementom fortepiano Zinaidoi Radchenko. [The Collection of Ukrainian and Belarusian Folk Songs of the Gomel District Recorded for Voice with Piano Accompaniment by Zinaida Radchenko.] St. Petersburg: V. Bessel' i Ko.

Radchenko, Zinaida 1888. Gomel'skie narodnye pesni (belorusskie i malorusskie). Zapisany v Dyatlovitskoy volosti Gomel'skogo uyezda Mogilevskoy gubernii Zinaidoy Radchenko. [Gomel Folk Songs.] St. Petersburg: Tip. V. Bezobrazova i K. Romanov, Evdokim 1886. Belorusskii sbornik. [Belarusian Collection.] Vol. 1: Guberniia Mogilevskaia, vyp.1/2: Pesni, poslovitsy, zagadki. [Mogilev Gubernia, Issue 1/2: Songs, Proverbs, Riddles.] Kiev: Tip. S. V. Kul'zhenko. Available at http:// avidreaders.ru/book/belorusskiy-sbornik-t-1-guberniya-mogilevskaya1.html, last accessed on 27 April 2018.

Sacharaŭ, Siarhiej 1940. Narodnaja tvorčasć lathaĺskich i ilukstenskich bielarusaŭ. [Folk Art of the Latgale Belarusians.] Rīgā: Latv. Baltkrievu Biedrības Izdevums.

Shein, Pavel 1874. Materialy dlia izucheniia byta i iazyka russkogo naseleniia SeveroZapadnogo kraia. [Materials for the Study of the Life and Language of the Russian Population of the Northwest Territory.] Vol. II. St. Petersburg: Imperatorskaia Akademiia Nauk.

Shein, Pavel 1873. Belorusskie narodnye pesni. [Belarusian Folk Songs.] Zapiski Imperatorskogo russkogo geograficheskogo obshchestva po otdeleniiu etnografii, Vol. 5. [Notes of the Russian Geographic Society.] St. Petersburg: Tipografiia V. N. Maikova.

Šyrma, Ryhor (ed.) 1959. Bielaruskija narodnyja piesni. [Belarusian Folk Songs.] Vol. 1. Minsk: n.p.

Šyrma, Ryhor (ed.) 1960. Bielaruskija narodnyja piesni. [Belarusian Folk Songs.] Vol. 2. Minsk: n.p.

Švied, Ina 2006. Kosmas i čalaviek u dendralahičnym kodzie bielaruskaha faĺkloru. [The Space and Humans in the Dendrology Code of the Belarusian Folklore.] Brest: n.p.

Švied, Ina 2011a. Mifalohija kolieru ŭ bielaruskaj tradycyjnaj duchoŭnaj kultury. [The Mythology of Color in Belarusian Traditional Spiritual Culture.] Brest: n.p.

Švied, Ina 2011b. Zialony. [Green.] Mifalohija bielarusaŭ. [Mythology of the Belarusians.] Minsk: Belarus, pp. 197-198.

Tsivyan, Tatiana 1990. Lingvisticheskie osnovy balkanskoi modeli mira. [Linguistic Bases of the Balkan Model of the World.] Moscow: Nauka. Available at http://inslav.ru/ publication/civyan-tv-lingvisticheskie-osnovy-balkanskoy-modeli-mira-m-1990, last accessed on 27 April 2018.

Tyszkiewicz, Konstanty (ed.) 1871. Wilija i jej brzegi: Pod względem hydrograficznym, historycznym, archeologicznym $i$ etnograficznym. [Vilija and Its Riversides.] Drezno: Drukiem I Nakladem J. I. Kraszewskiego. Available at http://pbc.biaman. pl/dlibra/doccontent?id=1690, last accessed on 27 April 2018.

Valodzina, Tacciana \& Vuhlik, Ihar 2011. Naga. [Leg.] Mifalohija bielarusaŭ. [Mythology of Belarusians.] Minsk: Belarus, p. 301.

Valodzina, Tacciana 2011. Noč. [Night.] Mifalohija bielarusaŭ. [Mythology of the Belarusians.] Minsk: Belarus, p. 330.

Varfalamiejeva, Tamara (ed.) 2001-2013. Tradycyjnaja mastackaja kultura bielarusaŭ: $U 6 t$. [The Traditional Artistic Culture of the Belarusian People.] Minsk: Belarusian Science. 